\title{
Global open-ocean biomes: mean and temporal variability
}

\author{
A. R. Fay ${ }^{1}$ and G. A. McKinley ${ }^{2}$ \\ ${ }^{1}$ Space Science and Engineering Center, University of Wisconsin-Madison, 1225 W. Dayton St., Madison, \\ Wisconsin 53706, USA \\ ${ }^{2}$ Department of Atmospheric and Oceanic Sciences, University of Wisconsin-Madison, 1225 W. Dayton St., \\ Madison, Wisconsin 53706, USA \\ Correspondence to: A. R. Fay (arfay@wisc.edu)
}

Received: 15 February 2014 - Published in Earth Syst. Sci. Data Discuss.: 26 March 2014

Revised: 28 June 2014 - Accepted: 16 July 2014 - Published: 21 August 2014

\begin{abstract}
Large-scale studies of ocean biogeochemistry and carbon cycling have often partitioned the ocean into regions along lines of latitude and longitude despite the fact that spatially more complex boundaries would be closer to the true biogeography of the ocean. Herein, we define 17 open-ocean biomes classified from four observational data sets: sea surface temperature (SST), spring/summer chlorophyll $a$ concentrations (Chl $a$ ), ice fraction, and maximum mixed layer depth (maxMLD) on a $1^{\circ} \times 1^{\circ}$ grid (available at doi:10.1594/PANGAEA.828650). By considering interannual variability for each input, we create dynamic ocean biome boundaries that shift annually between 1998 and 2010. Additionally we create a core biome map, which includes only the grid cells that do not change biome assignment across the 13 years of the time-varying biomes. These biomes can be used in future studies to distinguish large-scale ocean regions based on biogeochemical function.
\end{abstract}

\section{Introduction}

In recent decades, many studies have partitioned the pelagic environment into gyre- or subgyre-scale regions in order to investigate biogeochemical processes over large ocean regions (Longhurst, 1995; Sarmiento et al., 2004; Gurney et al., 2008; Reygondeau et al., 2013). Recent studies of the terrestrial carbon cycle have moved away from the division of the landmasses into latitudinally defined regions (Gurney et al., 2008). Despite the limitation of this latitudinal-defined approach in the oceans, recent observational and modeling studies have generally used such definitions (Gruber et al., 2009; Schuster et al., 2013). This is, at least in part, due to the lack of an alternative biome map available from the peerreviewed literature. Efforts to address this need date back to the 1980s when Emery and Meincke (1986) released a paper outlining global water masses based on temperature and salinity.

Biogeography is a discipline that seeks to identify ecosystem distributions across space and time (Cox and Moore,
2010). High costs and the three dimensions of space challenge our ability to observe the ocean, and thus most oceanographic sampling is sparse and heterogeneous. This, in turn, means that our knowledge of the detailed biogeography of the global oceans is more elementary than that for the terrestrial biosphere, though satellite-based estimates of surface ocean chlorophyll have helped to remedy this since the late 1990s. Ocean biogeochemistry is organized, to first order, by the large-scale ocean circulation, with frontal zones acting as boundaries, especially for the surface ocean (Longhurst, 2007). In this study, we take advantage of satellite chlorophyll and physical variables associated with large-scale circulation to define 17 surface ocean biomes that capture patterns of large-scale biogeochemical function at the basin scale. This work builds upon previous biome definitions (McKinley et al., 2011; Fay and McKinley, 2013), with the addition of ice fraction criteria. Additionally, in this study biome boundaries shift annually due to variability in the physical state and surface chlorophyll. 
In contrast to previous studies by Reygondeau et al. (2013) and Longhurst $(1995,2007)$ which consider subbasin-scale ocean provinces, the biomes presented here are for the open ocean and do not include coastal regions. These biomes are substantially larger than the provinces proposed initially by Longhurst (1995) in order to address the first-order differences in biogeochemical function at the scale of ocean gyres. Our goal is to partition the surface ocean into regions of common biogeochemical function at the largest possible scale. This goal is analogous to previous water-mass-boundaries work (Emery and Meincke, 1986; Iudicone et al., 2011), and is consistent with a variety of observational and modeling studies assessing air-sea $\mathrm{CO}_{2}$ fluxes and primary productivity (Sarmiento et al. 2004; Gurney et al., 2008; Gruber et al., 2009; Takahashi et al., 2009; Schuster et al., 2013).

Coastal oceans are important and diverse regions that constitute the transition zones between terrestrial and openocean regions. These regions are impacted by terrestrial runoff, tidal mixing and close coupling with the benthos. They receive from the land, and produce in situ, large amounts of organic matter. Coastal regions are very biogeochemically active. Thus, as has been traditional in biogeochemical oceanography, the coastal oceans are not grouped with open-ocean regions in this study (Sarmiento and Gruber, 2006). With respect to quantifying coastal carbon cycling, several groups are currently active. A North American effort is led by the Coastal Carbon Synthesis (CCARS) (http://www.whoi.edu/website/ccars/) and the European effort is included in the Blue Carbon Initiative (http: //thebluecarboninitiative.org/).

The ocean biomes presented here are of a similar scale to those used in RECCAP (the Regional Carbon Cycle Assessment Project), a global effort to establish the mean carbon balance and component fluxes of large regions of the globe (Wanninkhof et al., 2013). The regions used in RECCAP (available at http://transcom.lsce.ipsl.fr) are taken from those used in the TransCom atmospheric inversion intercomparison project (Gurney et al., 2008) and have become a standard for global ocean carbon research (Jacobson et al., 2007; Mikaloff-Fletcher et al., 2007; Gruber et al., 2009; Canadell et al., 2011; Lenton et al., 2013; Schuster et al., 2013). While there is substantial similarity between the biomes and the RECCAP regions, we will argue that the biomes presented here are preferable because they are defined by relevant environmental parameters instead of by lines of latitude. Going forward, these biomes could be used as a new basis for a wide range of analyses and intercomparison studies in ocean biogeochemistry and carbon cycling.

Herein, we present time-varying biomes for the global ocean, spanning from 1998 to 2010 (limited by chlorophyll $a$ data availability). We also present a mean biome map as well as a core biome map that assigns a biome classification only for those ocean grid cells that retain the same biome classification for all 13 years of the time-varying biomes.

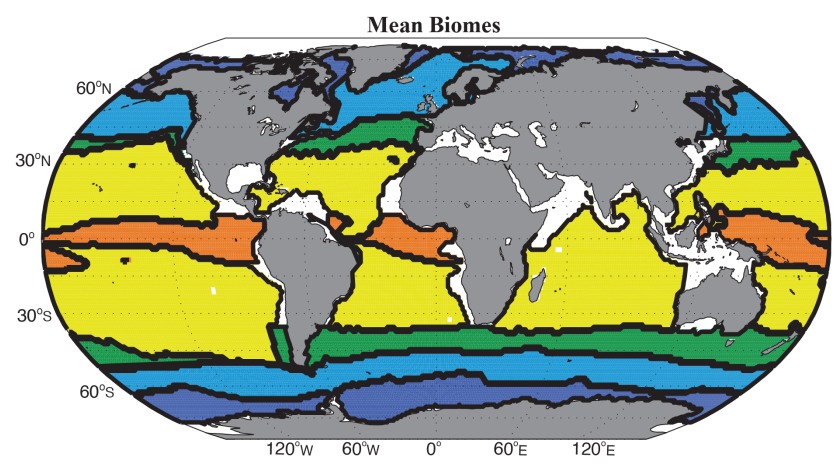

Figure 1. Mean biome map created from mean climatologies of maxMLD, SST, summer Chl $a$, and maximum ice fraction. Dark blue: ice biome (ICE); cyan: subpolar seasonally stratified biome (SPSS); green: subtropical seasonally stratified biome (STSS); yellow: subtropical permanently stratified biome (STPS); orange: equatorial biome (EQU). White indicates ocean areas that do not fit the criteria for any biome and are excluded from further analysis.

\section{Methodology}

We create physical, biologically defined regions or "biomes" delineated based on four climatological criteria: maximum mixed layer depth (maxMLD), spring/summer chlorophyll $a$ concentration (Chl $a$ ), sea surface temperature (SST), and sea ice fractional coverage (Table 1). SST has substantial latitudinal variation, and thus helps to separate subtropical from subpolar regions. SST also indicates major upwelling zones in the equatorial regions. maxMLD and Chl $a$ together indicate the amplitude of vertical mixing and the resulting seasonality in biogeochemical processing. Chl $a$ also separates the relatively unproductive subtropical regions from other regions. Sea ice fractional coverage is used to distinguish iceinfluenced biomes from subpolar biomes. The use of these observables as criteria is consistent with previous studies of ocean biogeography (Longhurst 1995, 2007; Sarmiento et al., 2004; Reygondeau et al., 2013; D’Ortenzio and d'Alcala, 2009).

The global open ocean is first divided into ocean basins (Atlantic, Pacific, Indian, and Southern Ocean) and then further classified into biomes, using the criteria in Table 1, starting from the poles: the ice biome (ICE), the subpolar seasonally stratified biome (SPSS), the subtropical seasonally stratified biome (STSS), the subtropical permanently stratified biome (STPS) and the equatorial biome (EQU). Biome assignments are made from pole to Equator for each hemisphere, beginning with the Northern Hemisphere (NH). This order is important as some biome's criteria are not mutually exclusive (specifically the EQU and South Pacific and Atlantic STPS biomes).

Provided here are maps for mean biomes, created using the mean climatology for years 1998-2010 (Fig. 1). Figure 2 shows the 13 years (1998-2010) of time-varying biomes, created using the annual data. Additionally, we create a core 

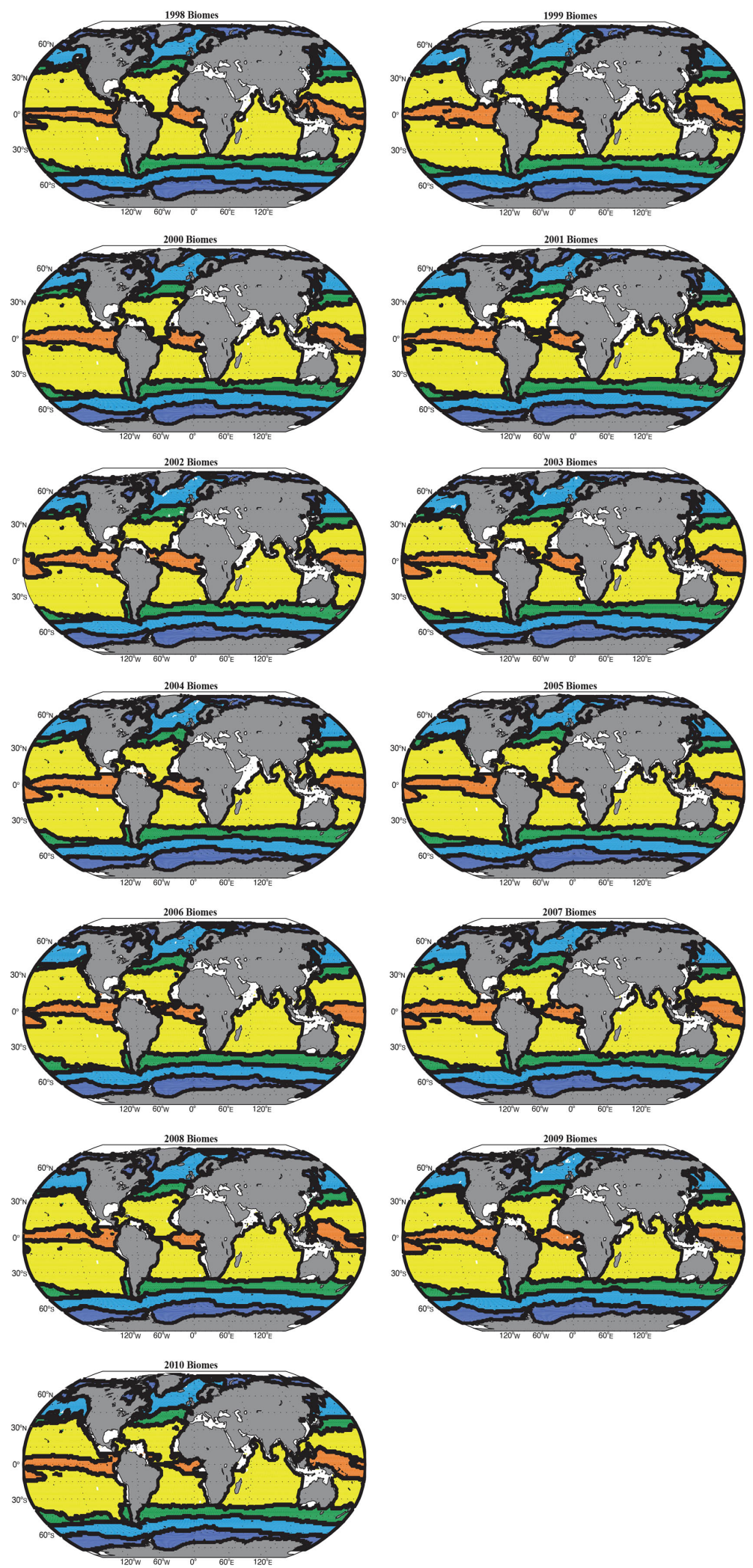

Figure 2. Time-varying biomes for years 1998-2010. Created from annual climatology of SST, summer mean Chl $a$, maximum ice fraction, and climatological maxMLD. Dark blue: ICE biome; cyan: SPSS biome; green: STSS biome; yellow: STPS biome; orange: EQU biome. White indicates ocean areas that do not fit the criteria for any biome and are excluded from further analysis. 
Table 1. Characteristics for the environmental envelopes defined for each biome. All criteria must be met for the biome to be assigned except where otherwise noted (STSS biomes). Chlorophyll is based on summer chlorophyll values.

\begin{tabular}{|c|c|c|c|c|c|}
\hline Biome & Sea ice fraction & $\operatorname{SST}\left({ }^{\circ} \mathrm{C}\right)$ & Chl $a\left(\mathrm{mg} \mathrm{m}^{-3}\right)$ & $\operatorname{maxMLD}(\mathrm{m})$ & Notes \\
\hline NH ICE & $x \geq 0.5$ & & & & \\
\hline N Pacific SPSS & & $x<14$ & $x \geq 0.25$ & & \\
\hline N Atlantic SPSS & & $x<14$ & $x \geq 0.4$ & & \\
\hline NH STSS & & $11 \leq x<29$ & $0.16 \leq x<0.4$ & $x>125$ & Either Chl $a$ or $\operatorname{maxMLD} ;$ lat $\geq 25^{\circ} \mathrm{N}$ \\
\hline NH STPS & & $14 \leq x<29$ & $x<0.16$ & $x \leq 125$ & \\
\hline IND STPS & & $x \geq 11$ & $x<0.25$ & & \\
\hline West Pacific EQU & & $x \geq 29$ & $x<0.25$ & & $15^{\circ} \mathrm{S} \leq$ latitude $\leq 15^{\circ} \mathrm{N}$ \\
\hline East Pacific EQU & & $19 \leq x<29$ & $0.16 \leq x<0.7$ & & $10^{\circ} \mathrm{S} \leq$ latitude $\leq 10^{\circ} \mathrm{N}$ \\
\hline Atlantic EQU & & $19 \leq x<29$ & $0.16 \leq x<0.7$ & & $10^{\circ} \mathrm{S} \leq$ latitude $\leq 10^{\circ} \mathrm{N}$ \\
\hline SH STPS & & $x \geq 8$ & $x<0.25$ & $x \leq 150$ & \\
\hline SH STSS & & $x \geq 8$ & $x \geq 0.16$ & $x>150$ & either Chl $a$ or maxMLD \\
\hline SH SPSS & & $x<8$ & & & \\
\hline SH ICE & $x \geq 0.5$ & & & & \\
\hline
\end{tabular}

biome map (Fig. 3), which only includes biome assignments for grid cells that retain the same biome assignment for all 13 years of the time-varying biomes.

\subsection{Biome descriptions}

Using the four criteria discussed in detail in Sects. 2.2-2.4, the ocean is divided into biomes. Each biome is characterized by a range of values from the observational fields (Table 1) and, if multiple criteria define a biome, all must be met for the grid cell to be assigned to that biome. The one exception to this is for the STSS biomes, which require either the Chl $a$ or the maxMLD criteria to be met. In all cases, the specific criteria used to define each biome have been developed to capture large-scale biogeochemical functioning while limiting the number of undefined regions between biome boundaries.

Cooler, polar waters that have at least a $50 \%$ ice-cover fraction during some part of the year are grouped into the marginal sea ice (ICE) biome.

SPSS biomes have divergent surface flow driven by the positive wind stress curl and thus upwelling from below, allowing for higher summer $\mathrm{Chl} a$ concentrations due to continual nutrient resupply. The Pacific and Atlantic oceans have different Chl $a$ constraints, with the Pacific being a high nutrient, low chlorophyll (HNLC) region (Sarmiento and Gruber, 2006; Table 1).

The STSS biome is an area of downwelling due to negative wind stress curl, but intermediate chlorophyll concentrations due to deep winter maxMLDs. The STPS biome experiences negative wind stress curl, leading to convergence and year-round stratification, such that maxMLDs are shallow and Chl $a$ is low. In the North Atlantic, spring runoff from the Amazon and Orinoco rivers cause a plume of high Chl $a$ levels in the eastern Caribbean area, excluding this region from STPS biome assignment.
EQU biomes are defined by SST and Chl $a$ constraints, coupled with latitudinal bounds, which are required because the criteria have similarity to coastal points at the edges of the STSS biomes (moderate temperatures and intermediate $\mathrm{Chl} a$ ). The Pacific equatorial biome is separated into east and west biomes, with the western EQU biome having warmer temperatures and lower Chl $a$ than the eastern. As easterlies blow across the equatorial region, warm water pools in the western half of the basin, causing warm temperatures and stratified waters with low Chl $a$. In the east Pacific, cool, high-nutrient waters are upwelled from depth, leading to higher Chl $a$. Similarly, in the Atlantic Ocean, warmer SSTs and moderate Chl $a$ levels define the EQU biome. In the Indian Ocean, the equatorial region is grouped in with the STPS biome due to seasonally varying physical ocean circulation patterns associated with the monsoon.

Ocean areas not defined by any of these biomes are largely coastal or influenced by coastal upwelling. Gulfs, bays, and seas such as the Mediterranean Sea and the Gulf of Mexico are not included in these biomes because these areas do not meet these biome criteria, designed for the open-ocean, due to their particular circulation patterns and/or strong influence from the land. A few open-ocean points also cannot be categorized into biomes by our criteria, and these points are omitted.

For calculation of the mean biomes, 1998-2010 mean Chl $a$, SST and sea ice fraction are used with climatological maxMLD.

\subsection{Monthly ice fraction and sea surface temperature}

The Hadley Centre Meteorological Office provides monthly mean gridded, global fractional sea ice coverage and SST from 1870 to present (HadISST - Hadley Centre Sea Ice and Sea Surface Temperature data set). The data set is described and its quality assessed by Rayner et al. (2003). This 
product is derived from gridded in situ observations with data-sparse regions filled using reduced space optimal interpolation (RSOI; Kaplan et al., 1997). For the period 19982010, the RSOI technique was applied to combined in situ and satellite data, with additional interpolation and smoothing procedures performed for the Southern Ocean. SST standard deviations for HadISST are shown for several regions in Sect. 6 of Rayner et al. (2003). Variance maximum occurs in the eastern equatorial Pacific and the coastal and Arctic regions of the global ocean. These patterns and magnitudes of variance are not unlike other SST products such as NOAA's OI (Optimum Interpolation) v2 product (Reynolds et al., 2002), while HadISST has reduced variance for other areas, such as the Indian Ocean.

HadISST sea ice coverage is reported as a fraction of each $1^{\circ} \times 1^{\circ}$ cell. A minimum threshold of 0.5 fractional coverage in any month of the year designates the ICE biome. This contrasts to Sarmiento et al. (2004), who define their ICE region as having any sea ice coverage in any part of the year. We use a more stringent ice criteria in order to ensure only waters influenced by ice year-round are included in the ICE biome. At the same time, we note that there is a relatively sharp transition (five grid cells or less) from no ice coverage $(<10 \%)$ to full coverage $(>90 \%)$ in HadISST, which means that a choice of a higher or lower percentage of coverage would have only limited impact on ICE biome extents.

For mean SST and sea ice fraction criteria, annual climatologies for years 1998-2010 are averaged. Specific criteria for each biome are presented in Table 1.

\subsection{Monthly chlorophyll a}

Chlorophyll $a$ concentration $(\mathrm{Chl} a$ ) is a proxy for the abundance of marine phytoplankton and offers a first-order quantification of rates of biogeochemical cycling in the surface ocean. Global ocean color data from the Sea-viewing Wide Field-of-view Sensor (SeaWiFS) satellite have been used to estimate Chl $a$ concentrations using NASA's OC4 (ocean color) algorithm (O'Reilly et al., 1998) (available at: http://oceandata.sci.gsfc.nasa.gov/). Monthly binned climatology products at $9 \mathrm{~km} \times 9 \mathrm{~km}$ resolution are provided by NASA beginning in September 1997 and ending in December 2010. Smigen, a NASA-provided program (available at http://seadas.gsfc.nasa.gov/doc/smigen/smigen.html) was used to recalculate monthly $\mathrm{Chl} a$ to $1^{\circ} \times 1^{\circ}$ resolution in a manner consistent with other SeaWiFS products.

The prelaunch accuracy target for SeaWiFS Chl $a$ was $35 \%$ for the range $0.05-0.50 \mathrm{mgm}^{-3}$ (Hooker et al., 1992), which is a common accuracy standard for satellite Chl $a$ products. O'Reilly et al. (1998) find the median percentage error for operational SeaWiFS compared to available open ocean in situ measurements to be $26 \%$.

In order to avoid bias due to high cloud coverage in winter, all biome selection is based on mean spring/summer Chl $a$ rather than an annual mean. The months April through
September are used in the Northern Hemisphere (NH), and December through March in the Southern Hemisphere (SH). Summer/spring is used because these months have the most consistent cloud-free coverage (over $75 \%$ of the Northern (Southern) Hemisphere has at least 5 (3) of the spring/summer months with coverage). The selected Chl $a$ criteria thresholds presented in Table 1 reflect this choice by being higher values than what would be used if annual mean Chl $a$ criteria had been selected.

We extend the Northern Hemisphere definition (AprilSeptember) to $10^{\circ} \mathrm{S}$ latitude in the construction of the biomes in order to have a consistent $\mathrm{Chl} a$ field for the equatorial biome assignment. Equatorial chlorophyll has a strong seasonal cycle. If the north-to-south switch in Chl $a$ definition were made at the Equator, regions just south of the Equator would reflect a 6-month phase shift in Chl $a$ values despite similar physics as regions just north of the Equator. This choice does not influence the Southern Hemisphere STPS biome because of the very small seasonal cycle in the STPS regions (the April-September mean is very similar to the December-March mean).

SeaWiFS data are not available for January-March 2008, which could impact Southern Hemisphere biomes for 2008 because December 2007 would be the only month with data. To avoid this potential bias, climatological summer Chl $a$ is used for the Southern Hemisphere biome classification for 2008.

\subsection{Climatological maximum mixed layer depth}

Climatological maxMLD indicates the amplitude of seasonality in biogeochemical processing, particularly in the transition regions between the subpolar and subtropical gyres where deep mixing provides nutrients to the otherwise oligotrophic surface ocean. Criteria for maxMLD are noted in Table 1. maxMLD does not vary annually because data are insufficient for global coverage.

Criteria for definition of the mixed layer and methods for finding its depth are numerous. We use the Argo mixed layer depth climatology (Holte et al., 2010) calculated with the density algorithm (Holte and Talley, 2009). Other threshold methods (de Boyer Montegut et al., 2004; Sarmiento et al., 2004) were also considered. The selected algorithm builds on traditional threshold and gradient methods by drawing its estimate of the MLD from physical features in the profile and by considering a pool of various MLDs from which the algorithm selects the final MLD estimate (Holte and Talley, 2009). The Argo climatology is based on data from years 2002-2008 that overlap reasonably well with the satellite chlorophyll record used here for our time-varying biomes (1998-2010). The de Boyer Montegut et al. (2004) climatology is based on earlier data (1941-2002) that have less overlap.

In some regions, most notably in the Southern and Arctic oceans, MLDs for some grid cells are not defined in the 
Argo climatology. These missing pixels are filled with a latitudinal mean from the same ocean basin. This filling occurs mostly in the higher latitudes and near continental shelves, where the maxMLD criterion is not applied for biome selection (Table 1). The maxMLD criterion is applied only to divide the STPS and STSS biomes, both of which have good coverage prior to filling.

\subsection{Smoothing}

After initial processing, each biome map is smoothed to limit the number of outlier grid cells within the biomes. An iterative smoothing process is used, cycling through the map numerous times and changing only the grid cells that are bordered on at least three sides by another biome classification.

The result of this automated, iterative smoothing is that each of the 13 years has between 350 and 467 grid cells change biome classification. For the 13 years of time-varying biomes, the maximum number of $1^{\circ} \times 1^{\circ}$ grid cells smoothed is 467 in the year 2002, which is $1.3 \%$ of the total grid cells in the global ocean. No more than $6 \%$ of the grid cells in any one biome change due to smoothing. Smoothing of the mean biomes changes 263 grid cells $(0.73 \%$ of total ocean grid cells and no more than $5 \%$ of any one biome). These smoothed areas occur most frequently in the intergyre regions (STSS), a region of strong interannual variability.

After smoothing, the core biomes are created by selecting only the grid cells that have the same biome definition in all of the 13 time-varying biomes.

\subsection{Data format and availability}

The biome maps are provided in netCDF-4 (network common data form) format (with an accompanying readme file) and can be found at the PANGAEA web page doi:10.1594/PANGAEA.828650 (or doi:10.1594/PANGAEA.828650). This contains files for the mean and core biome map boundaries as well as maps for each year of the time-varying biomes. An animation of the 13 time-varying biome maps is available at http://oceancarbon.aos.wisc.edu/biomes-2014/ and as a Supplement with this manuscript.

\section{Biomes}

Seventeen global biomes are represented on each of our biome maps using the criteria outlined in Table 1.

\subsection{Mean biomes}

Mean biomes are created using the climatological SST, Chl $a$, and ice fraction criteria for years 1998-2010, and climatological maxMLD with the criteria in Table 1. These biomes are presented in Fig. 1 with their areas listed in Table 2. From the poles, there are the marginal sea ice (ICE)
Table 2. Size (in $10^{6} \mathrm{~km}^{2}$ ) of the mean biomes and core biomes.

\begin{tabular}{lcc}
\hline Biome & $\begin{array}{c}\text { Mean biome area } \\
\left(10^{6} \mathrm{~km}^{2}\right)\end{array}$ & $\begin{array}{c}\text { Core biome area } \\
\left(10^{6} \mathrm{~km}^{2}\right)\end{array}$ \\
\hline NP ICE & 4.5852 & 3.9112 \\
NP SPSS & 12.838 & 8.7063 \\
NP STSS & 6.8257 & 4.3398 \\
NP STPS & 41.048 & 31.305 \\
Pac EQU W & 11.593 & 4.9040 \\
Pac EQU E & 14.890 & 7.7117 \\
SP STPS & 52.705 & 43.067 \\
NA ICE & 5.4750 & 4.6123 \\
NA SPSS & 10.062 & 7.8048 \\
NA STSS & 5.9744 & 4.6178 \\
NA STPS & 17.464 & 13.746 \\
Atl EQU & 7.4147 & 3.1972 \\
SA STPS & 18.055 & 16.056 \\
IND STPS & 35.936 & 32.383 \\
SO STSS & 29.692 & 23.670 \\
SO SPSS & 30.628 & 25.875 \\
SO ICE & 18.678 & 16.169 \\
\hline
\end{tabular}

biome and the subpolar gyres, or SPSS. Next come the intergyre regions between the subtropics and subpolar gyres, labeled STSS biomes. The subtropical gyres are classified as STPS biomes and the equatorial regions are included in the EQU biomes. The Indian Ocean is entirely a STPS biome. Going southward from the equatorial Atlantic and Pacific, we find the Southern Hemisphere subtropical gyres (STPS), and then the Southern Ocean regions that we define as STSS, SPSS and ICE biomes. Respectively, these three Southern Ocean biomes are comparable to the Subantarctic Zone (SAZ), the Polar Frontal Zone (PFZ) and Antarctic Zone (AZ) (Lovenduski et al., 2007).

\subsection{Time-varying biomes}

In Fig. 2 biome maps spanning years 1998-2010 are presented. Chl $a$ product availability is the limitation on the years of analysis. In each year, the criteria as listed in Table 1 are applied to annual data. Changes between these 13 maps are due to the combined impacts of changes in $\mathrm{Chl} a$, SST, and ice fraction from year to year. Due to lack of an interannually varying data product, maxMLD remains a climatological variable.

\subsection{Core biomes}

Core biomes are defined as the grid cells that maintain the same biome assignment for all 13 years (Fig. 3). With respect to analysis of variability or trends in biogeochemical variables, core biomes would be a conservative region for analysis because there is a strict consistency with the biome definition for each individual year between 1998 and 2010. Core biome areas are included in Table 2. 


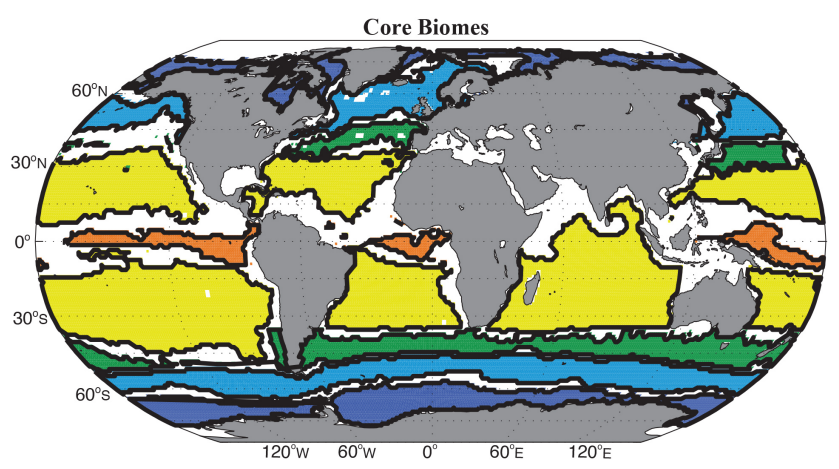

Figure 3. Core biome map. Core biomes are the portions of the 13 time-varying biomes that do not shift between one biome and another from year to year but remain as a single biome for all 13 years. Dark blue: ICE biome ; cyan: SPSS biome; green: STSS biome; yellow: STPS biome; orange: EQU biome. White indicates ocean areas that do not fit the criteria for any biome and also areas that shift biome assignments at least once between 1998 and 2010.
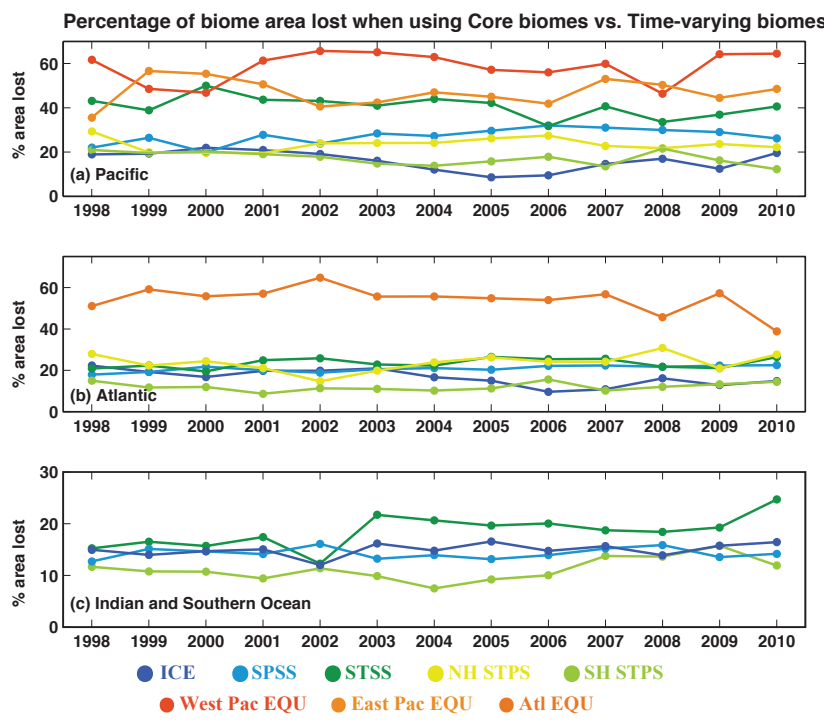

Figure 4. Percentage of biome area lost each year if using core biomes as compared to time-varying biomes for (a) Pacific Ocean, (b) Atlantic Ocean, and (c) Southern and Indian oceans. Dark blue: ICE; cyan: SPSS; green: STSS; yellow: Northern Hemisphere STPS; orange: EQU; light green: Southern Hemisphere STPS.

Undefined regions in the core biome map are caused by variability of the time-varying biomes. A comparison of the area of core biomes to the time-varying biomes indicates the degree of year-to-year variability in biome extent, with high percentages indicating more change (Fig. 4). The Pacific Basin shows the highest percentage of areas lost as compared to other basins (Fig. 4a). The greatest fraction of area omitted by the use of core biomes occurs in the equatorial, subtropical seasonally stratified, and subpolar biomes (> 25\% area excluded).
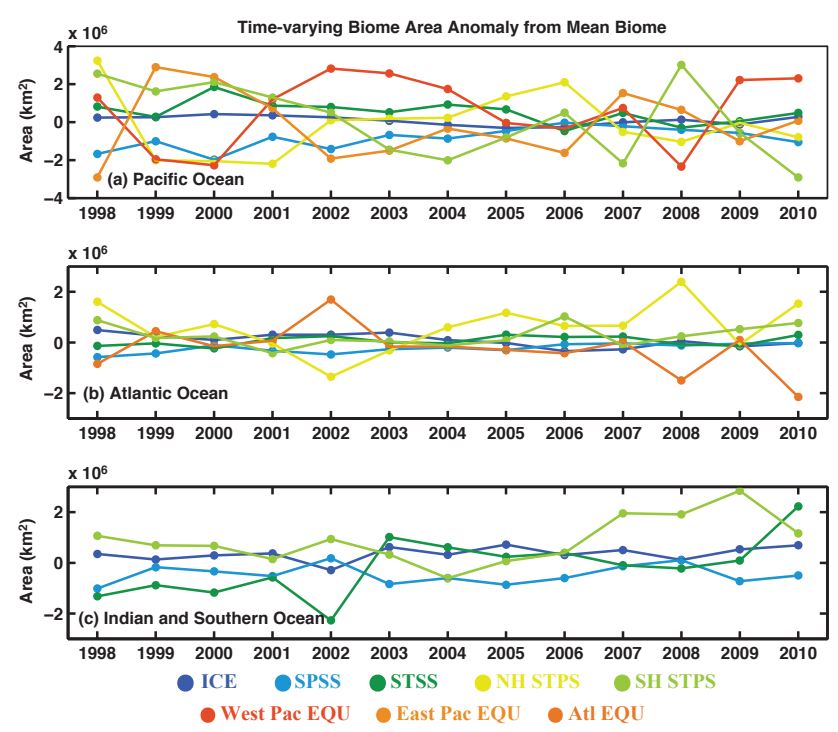

Figure 5. Biome area anomaly as the residual from the corresponding mean biome area for years 1998-2010 in (a) Pacific Ocean; (b) Atlantic Ocean; and (c) Southern and Indian oceans. Dark blue: ICE; cyan: SPSS; green: STSS; yellow: Northern Hemisphere STPS; orange: EQU; light green: Southern Hemisphere STPS.

A complimentary measure of interannual variability is the change in total biome area each year (Fig. 5). This is complimentary because latitudinal migration without change in total area allows for a small area anomaly (Fig. 5) and at the same time a significant percentage of area lost by use of the core biomes (Fig. 4).

Between the North Pacific SPSS and STSS biomes, the southern Gulf of Alaska shifts biomes year to year due to changing annual temperatures. Low productivity in some years also contributes to the northward recession of the North Pacific SPSS biome. This is reflected by the relatively high variability of the Pacific SPSS biome area (Fig. 5a) and high areas lost with the core biome for both biomes (Fig. 4a).

In the North Atlantic (NA) ICE biome, variation in ice fraction causes changing designation between ICE and SPSS, and therefore area lost in the core biomes (Fig. $4 \mathrm{~b}$ ). A significant inverse correlation $(r=-0.83)$ between NA ICE and NA SPSS biome areas further demonstrates this shift over the 13 years (Fig. 5b). Biome area changes are also large in the equatorial biomes (Fig. 5a, b) resulting in a high percentage of area loss in the core biomes (Fig. 4a, b).

Decreasing Chl $a$ in the northwestern Indian Ocean (IND) allows for the expansion of the IND STPS biome in the late 2000s (Fig. 5c). This could be related to weakening winds of the summer monsoon. Interannual change in Southern Ocean (SO) circulation impacts temperature and productivity causing biome areas to have substantial variability, particularly for SO STSS (Fig. 5c). This also results in a loss of area for the core biomes (Fig. 4c). 


\section{Discussion}

As first discussed by Longhurst (1995), ocean biogeography does not organize itself along lines of latitude and longitude. For example, in the surface ocean $p \mathrm{CO}_{2}$ climatology of Takahashi et al. (2009), it is clear in the North Atlantic and North Pacific that the subtropical-subpolar boundary follows the major ocean currents. Going forward, it will be advantageous to use biogeochemically relevant biomes in studies of large-scale ocean biogeochemistry and carbon cycling so as to avoid the limitations of square regions (Takahashi et al., 2006; Canadell et al., 2011). Schuster et al. (2013) note that the limited agreement in the seasonal cycle of North Atlantic air-sea $\mathrm{CO}_{2}$ fluxes from a range of methodologies is partially driven by the use of boundaries defined by latitude.

A visual comparison of the mean and core biomes to the Longhurst provinces and to the RECCAP regions is presented in Fig. 6. Largely, the biomes created here follow the outlines of one or of several Longhurst provinces. Major differences occur mostly in the intergyre regions of the North Atlantic and Pacific, in the South Pacific-Antarctic transition, and in the equatorial Atlantic. While Longhurst defines 56 provinces in his maps, many of these are specifically designed to capture marginal seas such as the Gulf of Mexico and the Arabian Sea or coastal regions. Only 30 Longhurst provinces are defined for the open ocean, and are thus most comparable to our 17 open-ocean biomes.

A comparison of the mean $\mathrm{Chl} a$ and $\mathrm{pCO}_{2}$ to the mean values at each $1^{\circ} \times 1^{\circ}$ grid cell contained within the biomes and those within the RECCAP regions confirms that the use of biome boundaries rather than latitude lines results in better large-scale spatial coherence of the fields. As an example, in the midlatitude North Atlantic Gulf Stream transition zone, the standard deviation of annual Chl $a$ is an order of magnitude larger when using RECCAP region 3 (Gruber et al., 2009; location indicated in Fig. 7c) vs. biome NA STSS $(0.40 \pm 1.29$ vs. $0.30 \pm 0.12$, respectively). This tendency persists in the subtropical North Atlantic $(0.21 \pm 0.76$ in RECCAP region 4 vs. $0.11 \pm 0.07$ in biome NA STPS) and North Pacific $(0.25 \pm 0.41$ in RECCAP region 13 vs. $0.09 \pm 0.044$ in biome NP STPS) as well as in the equatorial Pacific $(0.10 \pm 0.22$ in RECCAP region 16 vs. $0.10 \pm 0.046$ in the Pac EQU W biome; $0.20 \pm 0.42$ in RECCAP region 17 vs. $0.22 \pm 0.1$ in the Pac EQU E biome). In the Southern Ocean, interannual mean Chl $a$ variation is similar whether these biomes or the RECCAP regions are used, consistent with the biomes being more longitudinal. A similar comparison of the standard deviation of the long-term mean $p \mathrm{CO}_{2}$ between grid cells contained within biomes or RECCAP regions shows that the standard deviations of the individual points around the biome averages are smaller than around the RECCAP region averages in all cases except the Southern Ocean.

The seasonal cycles of climatological chlorophyll and $p \mathrm{CO}_{2}$ for two areas are shown in Fig. 7. The seasonal cycles of $p \mathrm{CO}_{2}$ for all grid cells within the NA STSS biome vs. grid cells within the RECCAP region 3 (Gruber et al., 2009) show a similar mean cycle, but there is more spread around the mean for the RECCAP region $(139 \mu \mathrm{atm})$ than for the biome (128 $\mu \mathrm{atm}$; Fig. 7a, b). A comparison of Chl $a$ seasonal cycles shows the same tendency - more variation around the mean for the RECCAP boundary coupled with a higher spring peak (RECCAP is $0.31 \mathrm{mg} \mathrm{m}^{-3}$, biome is $0.16 \mathrm{mg} \mathrm{m}^{-3}$; Fig. $7 \mathrm{e}, \mathrm{f}$ ).

In the western equatorial Pacific, the $p \mathrm{CO}_{2}$ seasonal cycle is smaller than at high latitudes, but still varies with the choice of regional definition (Fig. 7c, d). When using the biomes, the $p \mathrm{CO}_{2}$ climatology peaks during the winter months, whereas in RECCAP region $16, p \mathrm{CO}_{2}$ peaks in late summer. The standard deviation around the mean is larger

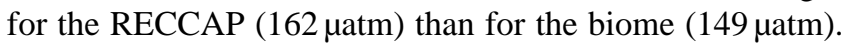
Considering Chl $a$, the standard deviation around the mean $\mathrm{Chl} a$ cycle for the RECCAP region is nearly double that of the variation around the biome mean cycle (RECCAP is $0.083 \mathrm{mg} \mathrm{m}^{-3}$, biome is $0.047 \mathrm{mg} \mathrm{m}^{-3}$; Fig. $7 \mathrm{~g}, \mathrm{~h}$ ).

These comparisons are representative of other biome to RECCAP region comparisons for the spatial coherence of the mean and seasonal cycles of $p \mathrm{CO}_{2}$ and $\mathrm{Chl} a$ within a large ocean area. Together, they suggest that biogeography is better defined by biomes than by lines of latitude.

Previous studies have proposed that the subtropical ocean regions are expanding and that warming ocean temperatures are contributing to reduced productivity in these important ocean gyres (Polovina et al., 2008; Behrenfeld et al., 2006). We find no significant trend in the area of any subtropical biome (STPS) over the years 1998-2010. In both the North Pacific and North Atlantic, the SPSS biome is expanding over the 1998-2010 time frame $\left(9.27 \pm 7.4810^{4} \mathrm{~km} \mathrm{yr}^{-1}\right.$; $\left.3.78 \pm 1.8610^{4} \mathrm{~km} \mathrm{yr}^{-1}\right)$. The SO STSS biome is also expanding $\left(1.98 \pm 1.4510^{5} \mathrm{~km} \mathrm{yr}^{-1}\right)$ as increasing Chl $a$ values at the South Pacific-Southern Ocean boundary allow it to extend further equatorward (Figs. 2, 5c). This SO STSS expansion persists for all time series longer than 10 years with end year 2010 (e.g., 1998-2010, 1999-2010, 20002010), however the signal disappears for trends ending prior to 2010. Likewise, a negative trend in the area of the North Pacific ICE biome appears for all trends longer than 10 years if the final year is prior to 2010 (Fig. 5a). When the area time series is extended to include 2010, this signal of declining area of the Pacific ICE biome disappears.

The North Atlantic ICE biome has a significant declining area trend for 1998-2010 $\left(-4.84 \pm 2.9010^{4} \mathrm{~km} \mathrm{yr}^{-1}\right)$ and a corresponding positive trend in the North Atlantic SPSS biome (3.78 $\pm 1.8910^{4} \mathrm{~km} \mathrm{yr}^{-1}$; Fig. 5b). The statistical significance of these trends persists for any 10-year or longer time series considered (i.e., 1998-2008, 1999-2009, 20002010, 1998-2009, etc.). As mentioned above, the 1998-2010 trends in NA ICE and SPSS biome areas are highly correlated $(r=-0.83)$. All trends reported here include their $95 \%$ confidence intervals calculated following Wilks (2006). As more data become available, significant secular trends in areas may 

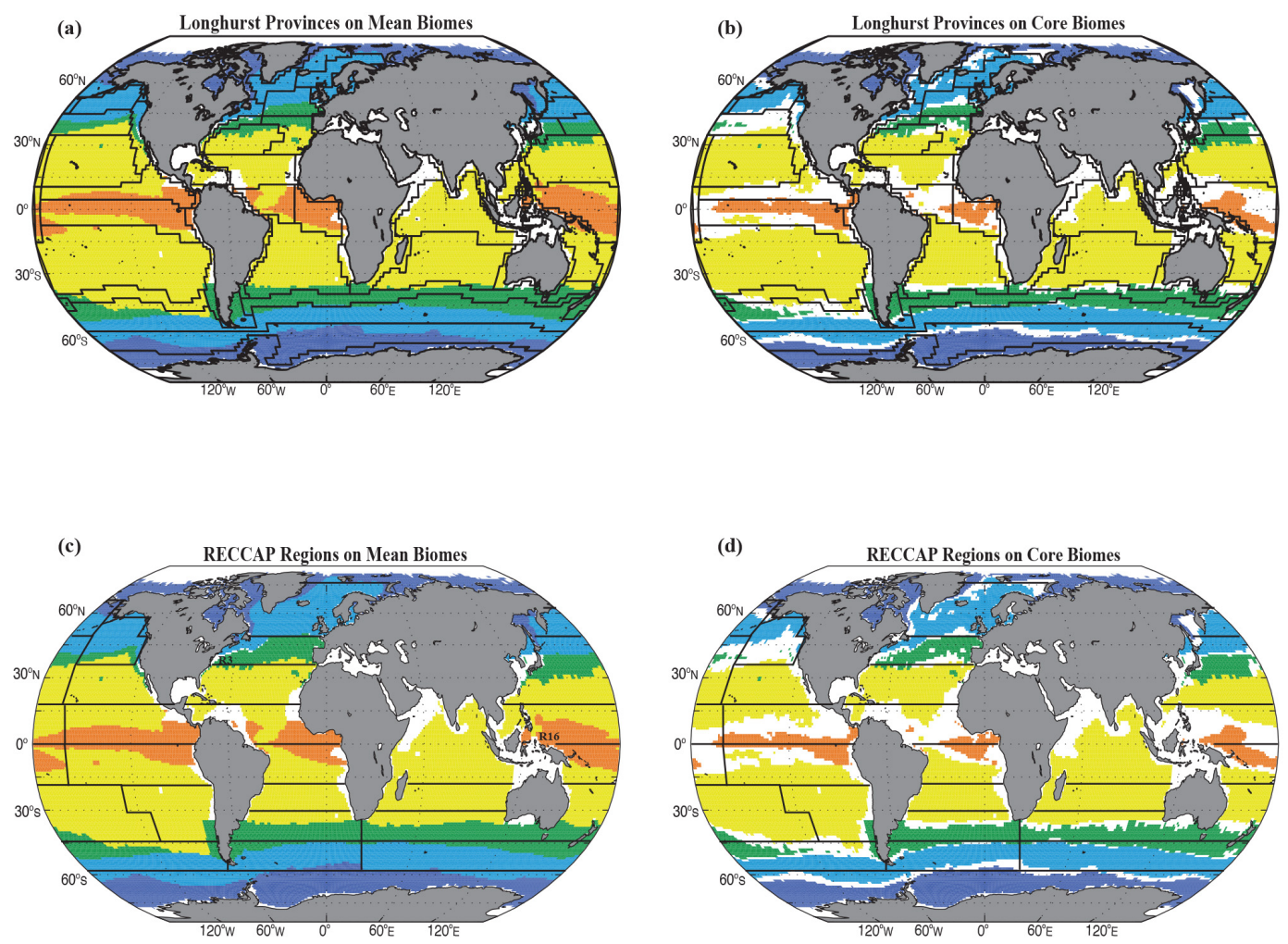

Figure 6. Longhurst's 56 provinces overlaid on top of (a) mean biomes and (b) core biomes; RECCAP ocean regions overlaid on top of (c) mean biomes and (d) core biomes. RECCAP regions 3 and 16 are labeled to facilitate interpretation of Fig. 7.

be revealed, but at present we find greater evidence for interannual variability.

The global biomes previously used to study surface ocean $p \mathrm{CO}_{2}$ trends (McKinley et al., 2011; Fay and McKinley, 2013) varied slightly from those presented here. Timevarying biomes were not used in these analyses. For the products presented here, biome criteria have been updated with the most current and complete data sets and products available. This results in some noticeable differences between the mean biome map presented here and that used in previous work by Fay and McKinley (2013). Changes in the North Atlantic biomes are primarily due to an improved mixed layer depth climatology. Changes in the extent of the ICE biomes are due to the inclusion of ice fraction as a criterion.

The data used as biome criteria have limitations. The main constraint is the lack of coverage for year-to-year change in mixed layer depth estimates. Mixed layer depth estimates should improve as Argo coverage expands. Extension of the time-varying biomes will be possible with updated HadISST products and new satellite $\mathrm{Chl} a$ estimates that extend beyond the SeaWiFS period. We have tried to use the current version of the GlobColour product in this analysis, but found substantial secular trends in equatorial biome areas after 2010 due to strong trends in GlobColour Chl $a .2010$ is the point where the SeaWiFS record ends, and these trends have not been validated in the literature. Thus, we did not use GlobColour in this analysis.

Biomes created with an alternate SST and sea ice concentration product (OI v2; Reynolds et al., 2002) result in smaller ice biomes and correspondingly larger SPSS biomes than those presented here. Other biomes had no significant change for either the mean or time-varying versions $(<1 \%$ of grid cells change for any biome). The core biome map has no notable differences when using this alternative SST and ice product.

Other recent works have defined many smaller bioregions over single-ocean basins or seas including the Southern Ocean (Grant et al., 2006) the Mediterranean Sea (D'Ortenzio and d'Alcala, 2009) and the Indian Ocean (Leìvy et al., 2007). These studies also used observed satellite chlorophyll, sea surface temperature, and other variables to define bioregions. These efforts have been detailed and focused on understanding the relatively small part of the ocean that they have subdivided into dozens of bioregions. However, these locally defined bioregions cannot be easily applied to other basins, as they are unique to the specific ocean. Regional definitions based on water masses are a relatively new and promising method of studying surface-to-deep connections in the ocean and climate modeling community, and have shown utility for global-scale comparison with respect to heat uptake and biogeochemical change due to climate 
(a)

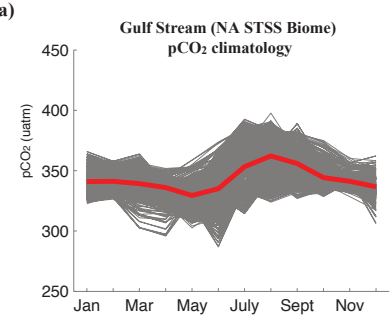

(c)

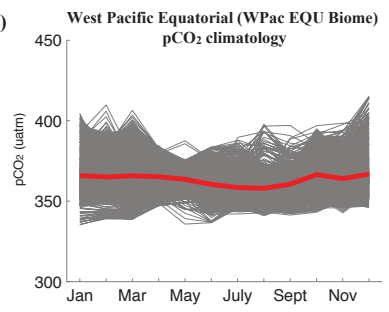

(e)

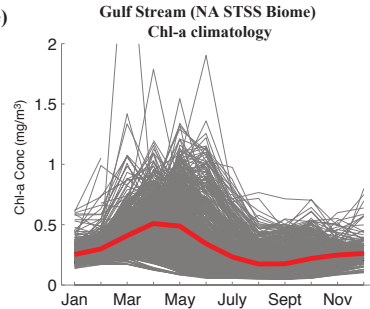

(g)

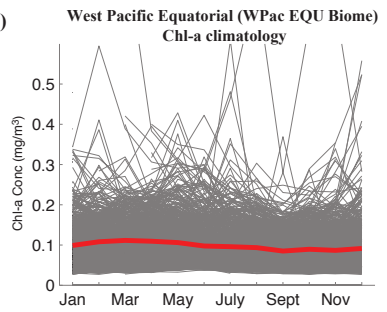

(b)
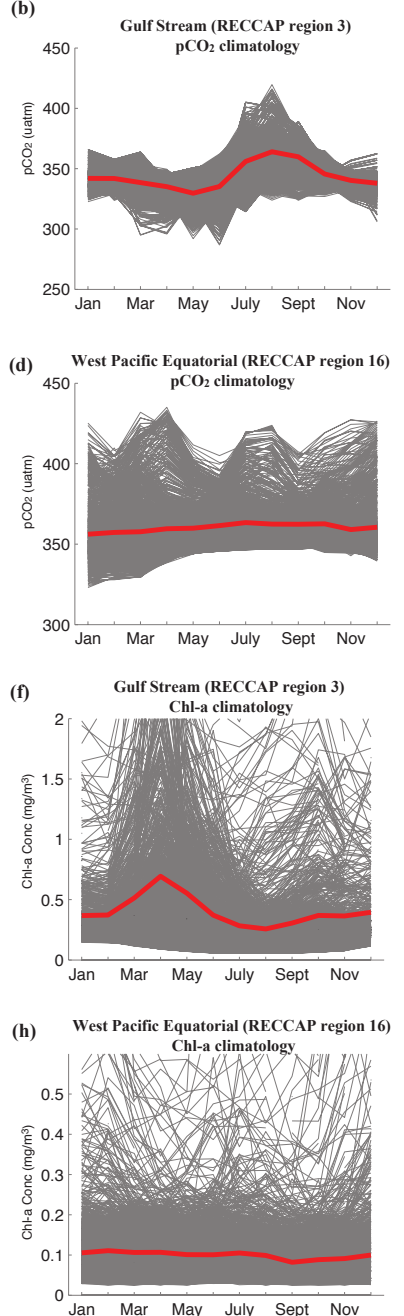

Figure 7. Comparison of biogeochemical variables in biomes vs. RECCAP regions 3 and 16. Seasonal $p \mathrm{CO}_{2}$ climatology (a-d) and Chl $a$ climatology (e-h) for two example regions: the North Atlantic Gulf Stream (a-b; e-f) and the west Pacific equatorial region (c-d; g-h).

change globally (Bopp et al., 2013) and in the Southern Ocean (Séférian et al., 2012; Sallée et al., 2013). Iudicone et al. $(2008,2011)$ discuss partitioning the domains using specific neutral density ranges to classify the water masses following Sloyan and Rintoul (2001). The biomes presented in this paper are meant to capture biogeochemical functioning at the surface ocean at the largest possible scale. Future comparisons to these previous studies offering regional definitions or water-mass-based partitioning will be of value.

These time-varying biomes offer a new basis for aggregation and analysis of biogeochemical data for global openocean studies. Utilizing these biomes may provide new insights on the response of the ocean biogeochemistry to climate change. For model intercomparison studies, where model physics such as currents and gyres can vary substan-

tially, defining model-specific biomes may be useful for comparison of trends and variability within and between models. The concise biome criteria presented should facilitate application to modeling studies, as the input data sets are typically standard output fields for global-scale models.

\section{Conclusions}

We offer three versions of environmentally defined biomes to be used as an alternative to the current standard of latitudinally defined ocean regions for biogeochemical and carbon cycle studies. The 17 mean biomes offer nearly full coverage of the open ocean and are based on mean data for years 19982010. Also presented are time-varying ocean biomes for each year from 1998 to 2010 that should be of use to studies focused in this period. Finally, core biomes can be utilized in analyses that wish to be most conservative in their definition by avoiding any points where the biome to which that point is assigned is not the same in all years between 1998 and 2010.

Opportunities for use of these biomes in future studies range from the aggregation of sparse data to the large-scale analysis of trends and seasonal cycles of surface biogeochemical properties. Clear distinction between biogeochemically different regions should improve comparisons of data and numerical models. Atmospheric and ocean inversion studies could use the mean biomes for their regional discretization (Gurney et al., 2008; Gruber et al., 2009). If the presented biomes are as widely adopted as the latitudinally defined regions have been, this advancement in biogeography may enrich future carbon-cycle intercomparison studies such as RECCAP (Canadell et al., 2011).

\section{The Supplement related to this article is available online at doi:10.5194/essd-6-273-2014-supplement.}

Acknowledgements. A. R. Fay and G. A. McKinley are supported by NASA grants 07-NIP07-0036, NNX/11AF53G, and NNX/13AC53G. We thank the editor and reviewers for their constructive comments that improved the manuscript.

Edited by: R. Key

\section{References}

Behrenfeld, M. J., O’Malley, R. T., Siegel, D. A, McClain, C. R., Sarmiento, J. L., Feldman, G. C., Milligan, A. J., Falkowski, P. G., Letelier, R. M., and Boss, E. S.: Climate-driven trends in contemporary ocean productivity, Nature, 444, 752-755, doi:10.1038/nature05317, 2006.

Bopp, L., Resplandy, L., Orr, J. C., Doney, S. C., Dunne, J. P., Gehlen, M., Halloran, P., Heinze, C., Ilyina, T., Séférian, R., Tjiputra, J., and Vichi, M.: Multiple stressors of ocean ecosystems in the 21st century: projections with CMIP5 models, 
Biogeosciences, 10, 6225-6245, doi:10.5194/bg-10-6225-2013, 2013.

Canadell, J. G., Ciais, P., Gurney, K., Le Quéré, C., Piao, S., Raupach, M. R., and Sabine, C. L.: An International Effort to Quantify Regional Carbon Fluxes, Eos Trans. AGU, 92(10), 81, 2011.

Cox, C. B. and Moore, P. D.: Biogeography: An Ecological and Evolutionary Approach, John Wiley \& Sons, Hoboken, NJ, 5-7, ISBN: 0470637943, 2010.

de Boyer Montégut, C., G. Madec, A. S. Fischer, Lazar, A., and Iudicone, D.: Mixed layer depth over the global ocean: An examination of profile data and a profile-based climatology, J. Geophys. Res., 109, C12003, doi:10.1029/2004JC002378, 2004.

D'Ortenzio, F. and Ribera d'Alcalà, M.: On the trophic regimes of the Mediterranean Sea: a satellite analysis, Biogeosciences, 6, 139-148, doi:10.5194/bg-6-139-2009, 2009.

Emery, W. J. and Meincke, J.: Global water masses-summary and review, Oceanol. Acta, 9, 383-391, 1986.

Fay, A. R. and McKinley, G. A.: Global trends in surface ocean $\mathrm{pCO}_{2}$ from in situ data, Global Biogeochem. Cy., 27, 541-557, doi:10.1002/gbc.20051, 2013.

Grant S., Constable, A., Raymond, and B., Doust, S.: Bioregionalisation of the Southern Ocean, Report of Experts Workshop, WWF- Australia and ACE CRC, Hobart, September, 2006.

Gruber, N., Gloor, M., Mikaloff Fletcher, S. E., Doney, S. C., Dutkiewicz, S., Follows, M. J., Gerber, M., Jacobson, A. R., Joos, F., Lindsay, K., Menemenlis, D., Mouchet, A., Müller, S. A., Sarmiento, J. L., and Takahashi, T.: Oceanic sources, sinks, and transport of atmospheric $\mathrm{CO}_{2}$, Global Biogeochem. Cy., 23, GB1005, doi:10.1029/2008GB003349, 2009.

Gurney, K. R., Baker, D., Rayner, P., and Denning, S.: Interannual variations in continental-scale net carbon exchange and sensitivity to observing networks estimated from atmospheric $\mathrm{CO}_{2}$ inversions for the period 1980 to 2005, Global Biogeochem. Cy., 22, GB3025, doi:10.1029/2007GB003082, 2008.

Holte, J. and Talley, L.: A New Algorithm for Finding Mixed Layer Depths with Applications to Argo Data and Subantarctic Mode Water Formation, J. Atmos. Oceanic Tech., 26, 19201939, doi:10.1175/2009JTECHO543.1, 2009.

Holte, J., Gilson, J., Talley, L., and Roemmich D.: Argo Mixed Layers, Scripps Institution of Oceanography/UCSD, http:// mixedlayer.ucsd.edu (last access: 14 March 2014), 2010.

Hooker, S. B., Esaias, W. E., Feldman, G. C., Gregg, W. W., and McClain, C. R.: An overview of SeaWiFS and ocean color, NASA Tech. Memo. 104566, Vol. 1, 24 pp., 1992.

Iudicone, D., Madec, G., and McDougall, T. J.: Water-mass transformations in a neutral density framework and the key role of light penetration, J. Phys. Oceanogr., 38, 1357-1376, 2008.

Iudicone, D., Rodgers, K. B., Stendardo, I., Aumont, O., Madec, G., Bopp, L., Mangoni, O., and Ribera d'Alcala', M.: Water masses as a unifying framework for understanding the Southern Ocean Carbon Cycle, Biogeosciences, 8, 1031-1052, doi:10.5194/bg-81031-2011, 2011.

Jacobson, A. R., Mikaloff-Fletcher, S. E., Gruber, N., Sarmiento, J. L., and Gloor, M.: A joint atmosphere-ocean inversion for surface fluxes of carbon dioxide: 2. Regional results, Global Biogeochem. Cy., 21, GB1019, doi:10.1029/2006GB002703, 2007.

Kaplan, A., Kushnir, Y., Cane, M. A., and Blumenthal, M. B.: Reduced space optimal analysis for historical data sets: 136 years of Atlantic sea surface temperatures, J. Geophys. Res.-Oceans, 102, 27835-27860, 1997.

Lenton, A., Tilbrook, B., Law, R. M., Bakker, D., Doney, S. C., Gruber, N., Ishii, M., Hoppema, M., Lovenduski, N. S., Matear, R. J., McNeil, B. I., Metzl, N., Mikaloff Fletcher, S. E., Monteiro, P. M. S., Rödenbeck, C., Sweeney, C., and Takahashi, T.: Seaair $\mathrm{CO}_{2}$ fluxes in the Southern Ocean for the period 1990-2009, Biogeosciences, 10, 4037-4054, doi:10.5194/bg-10-4037-2013, 2013.

Leìvy, M., Shankar, D., Andreì, J.-M., Shenoi, S. S. C., Durand, F., and de Boyer Monteìgut, C.: Basin-wide seasonal evolution of the Indian Ocean's phytoplankton blooms, J. Geophys. Res., 112, C12014, doi:10.1029/2007JC004090, 2007.

Longhurst, A.: Seasonal cycles of pelagic production and consumption, Prog. Oceanogr., 36, 77-167, doi:10.1016/00796611(95)00015-1, 1995.

Longhurst, A. R.: Ecological geography of the sea, Academic Press, Elsevier Inc., Burlington, MA, Pg: 35-40, 89-113, ISBN: 9780-12-455521-1, 2007.

Lovenduski, N. S., Gruber, N., Doney, S. C., and Lima, I. D.: Enhanced $\mathrm{CO}_{2}$ outgassing in the Southern Ocean from a positive phase of the Southern Annular Mode, Global Biogeochem. Cy., 21, doi:10.1029/2006GB002900, 2007.

McKinley, G. A., Fay, A. R., Takahashi, T., and Metzl, N.: Convergence of atmospheric and North Atlantic carbon dioxide trends on multidecadal timescales, Nat. Geosci., 4, 606-610, doi:10.1038/ngeo1193, 2011.

Mikaloff-Fletcher, S. E., Gruber, N., Jacobson, A. R., Gloor, M., Doney, S. C., Dutkiewicz, S., Gerber, M., Follows, M., Joos, F., Lindsay, K., Menemenlis, D., Mouchet, A., Müller, S. A., and Sarmiento, J. L.: Inverse estimates of the oceanic sources and sinks of natural $\mathrm{CO}_{2}$ and the implied oceanic carbon transport, Global Biogeochem. Cy., 21, GB1010, doi:10.1029/2006GB002751, 2007.

O’Reilly, J. E., Maritorena, S., Mitchell, B. G., Siegel, D. A., Carder, K. L., Garver, S. A., Kahru, M., and McClain, C.: Ocean color chlorophyll algorithms for SeaWiFS, J. Geophys. Res., 103, 24937, doi:10.1029/98JC02160, 1998.

Polovina, J. J., Howell, E. A., and Abecassis, M.: Ocean's least productive waters are expanding, Geophys. Res. Lett., 35, L03618, doi:10.1029/2007GL031745, 2008.

Rayner, N. A., Parker, D. E., Horton, E. B., Folland, C. K., Alexander, L. V., Rowell, D. P., Kent, E. C., and Kaplan, A.: Global analyses of sea surface temperature, sea ice, and night marine air temperature since the late nineteenth century, J. Geophys. Res., 108, 4407, doi:10.1029/2002JD002670, 2003.

Reygondeau, G., Longhurst, A., Martinez, E., Beaugrand, G., Antoine, D., and Maury, O.: Dynamic biogeochemical provinces in the global ocean, Global Biogeochem. Cy., 27, 1046-1058, doi:10.1002/gbc.20089, 2013.

Reynolds, R. W., Rayner, N. A., Smith, T. M., Stokes, D. C., and Wang, W.: An improved in situ and satellite SST analysis for climate, J. Climate, 15, 1609-1625, 2002.

Sallée, J. B., Shuckburgh, E., Bruneau, N., Meijers, A. J. S., Bracegirdle, T. J., Wang, Z., and Roy, T.: Assessment of Southern Ocean water mass circulation and characteristics in CMIP5 models: Historical bias and forcing response, J. Geophys. Res.Oceans, 118, 1830-1844, doi:10.1002/jgrc.20135, 2013. 
Sarmiento, J. L., Slater, R., Barber, R., Bopp, L., Doney, S. C., Hirst, A. C., Kleypas, J., Matear, R., Mikolajewicz, U., Monfray, P., Soldatov, V., Spall, S. A., and Stouer, R.: Response of ocean ecosystems to climate warming, Global Biogeochem. Cy., 18, GB3003, doi:10.1029/2003GB002134, 2004.

Sarmiento, J. L. and Gruber, N.: Ocean Biogeochemical Cycles, Princeton University Press, Princeton, NJ, 503 pp., 2006.

Schuster, U., McKinley, G. A., Bates, N., Chevallier, F., Doney, S. C., Fay, A. R., González-Dávila, M., Gruber, N., Jones, S., Krijnen, J., Landschützer, P., Lefèvre, N., Manizza, M., Mathis, J., Metzl, N., Olsen, A., Rios, A. F., Rödenbeck, C., SantanaCasiano, J. M., Takahashi, T., Wanninkhof, R., and Watson, A. J.: An assessment of the Atlantic and Arctic sea-air $\mathrm{CO}_{2}$ fluxes, 1990-2009, Biogeosciences, 10, 607-627, doi:10.5194/bg-10607-2013, 2013.

Séférian, R., Iudicone, D., Bopp, L., Roy, T. and Madec, G.: Water Mass Analysis of Effect of Climate Change on Air-Sea $\mathrm{CO}_{2}$ Fluxes: The Southern Ocean, J. Climate, 25, 3894-3908, doi:10.1175/JCLI-D-11-00291.1, 2012.

Sloyan, B. M. and Rintoul, S. R.: The Southern Ocean limb of the global deep overturning circulation, J. Phys. Oceanogr., 31, 143$173,2001$.
Takahashi, T., Sutherland, S. C., Feely, R. A., and Wanninkhof, R.: Decadal change of the surface water $\mathrm{pCO}_{2}$ in the North Pacific: A synthesis of 35 years of observations, J. Geophys. Res., 111, C07S05, doi:10.1029/2005JC003074, 2006.

Takahashi, T., Sutherland, S. C., Wanninkhof, R., Sweeney, C., Feely, R. A., Chipman, D. W., Hales, B., Friederich, G., Chavez, F., Sabine, C., Watson, A., Bakker, D. C. E., Schuster, U., Metzl, N., Yoshikawa-Inoue, H., Ishii, M., Midorikawa, T., Nojiri, Y., Körtzinger, A., Steinho, T., Hoppema, M., Olafsson, J., Arnarson, T. S., Tilbrook, B., Johannessen, T., Olsen, A., Bellerby, R., Wong, C. S., Delille, B., Bates, N. R., and de Baar, H. J. W.: Climatological mean and decadal change in surface ocean $\mathrm{pCO}_{2}$, and net sea-air $\mathrm{CO}_{2}$ flux over the global oceans, Deep Sea Res. Pt II, 56, 554-577, doi:10.1016/j.dsr2.2008.12.009, 2009.

Wanninkhof, R., Park, G. -H., Takahashi, T., Sweeney, C., Feely, R., Nojiri, Y., Gruber, N., Doney, S. C., McKinley, G. A., Lenton, A., Le Quéré, C., Heinze, C., Schwinger, J., Graven, H., and Khatiwala, S.: Global ocean carbon uptake: magnitude, variability and trends, Biogeosciences, 10, 1983-2000, doi:10.5194/bg10-1983-2013, 2013.

Wilks, D. S.: Statistical Methods in the Atmospheric Sciences, 627 pp., Elsevier, Amsterdam, 2006. 